\title{
Kinetic Study and Scaleup of the Oxidation of Nanofiltration Retentates by $\mathrm{O}_{3}$
}

\author{
Steven Van Geluwe, ${ }^{* \dagger}{ }^{\dagger}$ Jan Degrève, ${ }^{\dagger}$ Chris Vinckier, ${ }^{\ddagger}$ Leen Braeken, ${ }^{\dagger}{ }^{\S}$ Claude Creemers, ${ }^{\dagger}$ \\ and Bart Van der Bruggen ${ }^{\dagger}$
}

${ }^{\dagger}$ Laboratory of Applied Physical Chemistry and Environmental Technology, Department of Chemical Engineering, K.U. Leuven, W. de Croylaan 46, 3001 Leuven, Belgium

${ }^{\ddagger}$ Laboratory of Molecular Design and Synthesis, Department of Chemistry, K.U. Leuven, Celestijnenlaan 200F, 3001 Leuven, Belgium

${ }^{\S}$ Department of Industrial Sciences and Technology, KHLim Universitaire Campus, Gebouw B Bus 3, 3590 Diepenbeek, Belgium

\section{Supporting Information}

ABSTRACT: This paper reports on the upscaling of an $\mathrm{O}_{3}$ reactor for the oxidation of natural organic matter. Natural organic matter is responsible for fouling of nanofiltration membranes used for drinking water production. The proposed concept is to feed the retentate stream of a nanofiltration module $\left(400 \mathrm{~m}^{3} \mathrm{~h}^{-1}\right)$ to an $\mathrm{O}_{3}$ reactor (bubble column) and subsequently recycle it to a second nanofiltration module. The $\mathrm{O}_{3}$ oxidation of the retentate stream in the bubble column is analyzed in terms of the two-film theory with mass transfer and chemical reaction. The kinetic regime of the ozonation process, i.e., the chemical reaction rate relative to the mass-transfer rate, is determined using data from laboratory-scale experiments. This information is used for the calculation of the reactor volume and the required $\mathrm{O}_{3}$ dose on an industrial scale. An economic assessment of the integrated nanofiltration $-\mathrm{O}_{3}$ oxidation process also is given.

\section{INTRODUCTION}

Nanofiltration (NF) is an effective and reliable method for the combined removal of a broad range of pollutants in surface water, such as natural organic matter $(\mathrm{NOM})^{1}$ and several micropollutants. ${ }^{2}$ This makes NF an appropriate technology for the production of drinking water from surface water. However, fouling of the membranes results in a reduction in water flux, which leads to higher treatment costs. Membrane fouling also limits the water recovery, i.e., the ratio of the permeate (potable water) flow rate to the feed flow rate. A water recovery of $\sim 80 \%$ is typically achieved in the drinking water industry. The remaining fraction, the retentate stream, is usually discharged into surface water bodies. ${ }^{3}$ Since problems with water scarcity are expected to grow worse in the coming decades, even in regions that are currently considered to be water-rich, ${ }^{4}$ wasting $20 \%$ of the feedwater is questionable.

$\mathrm{O}_{3}$ oxidation of the retentate stream is proposed as a possible way to resolve this problem. It is well-known that $\mathrm{O}_{3}$ oxidation decomposes the NOM, which is an important membrane foulant, that is present in the retentate stream. ${ }^{5}$ The effect of $\mathrm{O}_{3}$ oxidation of the retentate on the flux of several commercial NF membranes (NF 270, Desal 51 HL, NF-PES 10, and NF 90) has been studied in one of our previous publications. ${ }^{6}$ The results of these experiments are summarized in Table 1, where the membrane permeabilities for retentate solutions after $\mathrm{O}_{3}$ oxidation are compared to the membrane permeabilities for untreated retentate solutions. The permeability of a membrane is calculated as the permeate flow rate (given in liters, L) per square meter membrane $\left(\mathrm{m}^{-2}\right)$, per hour $\left(\mathrm{h}^{-1}\right)$, and per unit pressure difference across the membrane $\left(\mathrm{bar}^{-1}\right)$. A comparison between different membranes can be made easier by calculating the relative permeability of each membrane (see the figures between the brackets in Table 1). The relative permeability is equal to the membrane permeability divided by the pure water permeability of the membrane in question, so that a figure between 0\% (no flux) and 100\% (no fouling) is obtained. Concerning the experimental conditions in the $\mathrm{O}_{3}$ reactor, the residence time of a retentate solution in this reactor ranged between $6 \mathrm{~min}$ and $20 \mathrm{~min}$, while the $\mathrm{O}_{3}$ concentration in the gas phase was kept constant $\left(12.2 \pm 0.4 \mathrm{mg} \mathrm{L}^{-1}\right)$. In this way, the specific $\mathrm{O}_{3}$ dose ranged between 24 and $80 \mathrm{~g} \mathrm{O}_{3}$ per $\mathrm{m}^{3}$ retentate, assuming that the transfer efficiency of $\mathrm{O}_{3}$ from the gas phase to the liquid is $100 \%$. The $\mathrm{pH}$ of the retentate solutions ranged between 7.7 and 8.4, and it did not change appreciably during the ozonation experiments.

The results in Table 1 show that $\mathrm{O}_{3}$ oxidation is able to alleviate membrane fouling for all investigated membranes. The increase of the relative membrane permeabilities after $\mathrm{O}_{3}$ oxidation (see the bottom line in Table 1) was quite similar at the different $\mathrm{O}_{3}$ doses: $18.1 \pm 1.9 \%$ for the membrane NF $270,15.3 \pm 6.3 \%$ for Desal 51, and $16.5 \pm 2.8 \%$ for NF-PES 10 . For the NF 90 membrane, the variation was higher (31.1 \pm $17.2 \%)$, but also here, no clear trend could be observed when changing the $\mathrm{O}_{3}$ dose. These observations were explained in terms of the hydrophobicity and the molecular mass of the NOM. ${ }^{5,6}$ It could be shown that $\mathrm{O}_{3}$ reacts very efficiently with unsaturated $\mathrm{C}-\mathrm{C}$ bonds (measured by the UV absorbance) that are abundant in the hydrophobic fraction of the NOM (measured by the hydrophobic COD). These hydrophobic

Received: September 9, 2011

Revised: $\quad$ March 21, 2012

Accepted: April 27, 2012

Published: April 27, 2012 
Table 1. Membrane Permeabilities after $40 \mathrm{~h}$ of Filtration of the NF Retentate Streams, before and after $\mathrm{O}_{3} \mathrm{Oxidation}$

\begin{tabular}{lcccc} 
& \multicolumn{4}{c}{ Membrane Permeability $\left(\mathrm{L} \mathrm{m}^{-2} \mathrm{~h}^{-1} \text { bar }^{-1}\right)^{a}$} \\
\cline { 2 - 5 } NF membrane & NF 270 & Desal 51 HL & NF-PES 10 & NF 90 \\
treated with $\mathrm{O}_{3}$ & $11.09(82.3 \%)$ & $10.92(72.7 \%)$ & $9.37(73.7 \%)$ & $6.66(69.6 \%)$ \\
untreated & $9.27(64.2 \%)$ & $8.61(57.4 \%)$ & $7.77(57.2 \%)$ & $3.89(38.5 \%)$ \\
flux increase & $18.1 \pm 1.9 \%$ & $15.3 \pm 6.3 \%$ & $16.5 \pm 2.8 \%$ & $31.1 \pm 17.2 \%$
\end{tabular}

${ }^{a_{\text {The }}}$ percentages shown in parentheses are the ratios of the respective permeability to the pure water permeability of the membrane in question (100\% means no membrane fouling).

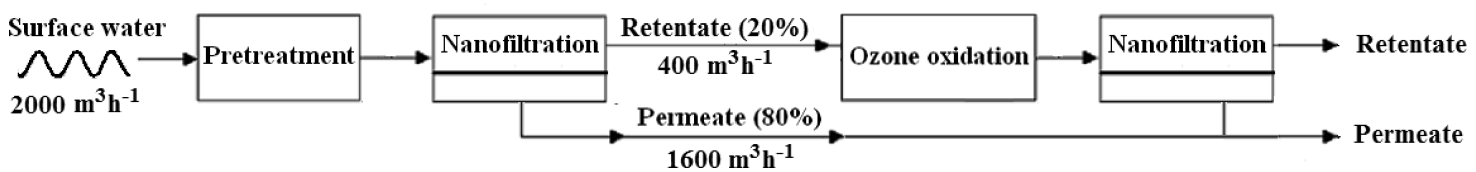

Figure 1. Simplified process flow diagram of the full-scale plant.

components readily adsorb on the membrane surface (mostly a semiaromatic polyamide). They are transformed to saturated bonds by $\mathrm{O}_{3}$ (mostly carbonyl and carboxyl groups), which are relatively hydrophilic, making the adsorption of NOM onto the membrane surface more difficult. A lower thickness of the fouling layer if $\mathrm{O}_{3}$ oxidation is applied to the retentate solution confirms this explanation. In addition, $\mathrm{O}_{3}$ oxidation shifts the molecular mass distribution of the NOM to smaller fragments, but this effect is small, compared to the effect of $\mathrm{O}_{3}$ on the hydrophobic COD and the UV absorbance. Further details can be found in other work by Van Geluwe et al. ${ }^{6}$

Concerning the full-scale plant, suppose that surface water $\left(2000 \mathrm{~m}^{3} \mathrm{~h}^{-1}\right)$ is prefiltered and fed into a first NF module. Assume that the water recovery of this module is $80 \%$. The retentate stream $\left(400 \mathrm{~m}^{3} \mathrm{~h}^{-1}\right)$ is fed into an $\mathrm{O}_{3}$ reactor where an $\mathrm{O}_{3}$ containing gas stream is introduced at the bottom of the reactor and bubbles through the liquid solution. The ozonated retentate stream subsequently flows to a second NF module (see Figure 1). The $\mathrm{O}_{3}$ oxidation of the retentate stream in the bubble column is a heterogeneous process, i.e., $\mathrm{O}_{3}$ gas can react with the target pollutant(s) after it is absorbed into the liquid phase. The kinetic equations of the ozonation process are based on the two-film theory proposed by Lewis and Whitman. ${ }^{7}$ This is discussed in the Supporting Information. The kinetic equations involve not only chemical reaction rate constants, but also mass-transfer coefficients. Therefore, the physical parameters (such as the volumetric mass-transfer coefficient $\left(k_{L} a\right)$ and the gas holdup $\left.(\varepsilon)\right)$ and the chemical parameters (such as the apparent reaction rate constant $k_{\text {app }}$ between $\mathrm{O}_{3}$ and NOM, the Hatta number $\left(M_{H}\right)$ and the enhancement factor $(E)$ ) of the ozonation process must be determined. The purpose of this article is to use the information obtained by laboratory-scale experiments for the determination of the kinetic regime and the dimensioning of the $\mathrm{O}_{3}$ reactor on an industrial scale. An economic evaluation of membrane fouling alleviation by $\mathrm{O}_{3}$ oxidation also is presented.

The literature concerning engineering of $\mathrm{O}_{3}$ units focuses on the ozonation of waters which contain no organic matter ("pure water") ${ }^{8-10}$ and $\mathrm{O}_{3}$ disinfection of waters with a low organic content. $^{11-13}$ The $\mathrm{O}_{3}$ oxidation of water streams with a relatively high NOM concentration has hardly been investigated from an engineering point of view. The results of this study will allow understanding of fundamental effects related to scaleup and practical application of $\mathrm{O}_{3}$ oxidation for membrane fouling alleviation. 5,6

\section{MATERIALS AND METHODS}

2.1. Preparation of the Nanofiltration Retentate Solutions. Surface water was taken from the Dijle river in Leuven, Belgium. The Dijle water was prefiltered by the cellulose filters MN 713 1/4 (Macherey-Nagel, Germany), S\&S 595 and S\&S 589/3 (both from Schleicher \& Schüll, Germany). These three paper filtrations minimized the concentration of suspended particles with a size larger than $2.5 \mu \mathrm{m}$ in the feed solution. These paper filtrations were carried out to simulate the pretreatment of the feedwater in full-scale plants, e.g., the Méry-sur-Oise plant in France, where the number of particles $>1.5 \mu \mathrm{m}$ passing through the membranes was kept to less than 100 per $\mathrm{mL}^{14}$

The retentate solution was obtained by filtering the prefiltered Dijle water with the NF 270 membrane (FilmTec, USA). This was performed in a cross-flow setup on laboratory scale (batch operation) (Amafilter, The Netherlands). The experimental setup is shown in Figure 2. The equipment

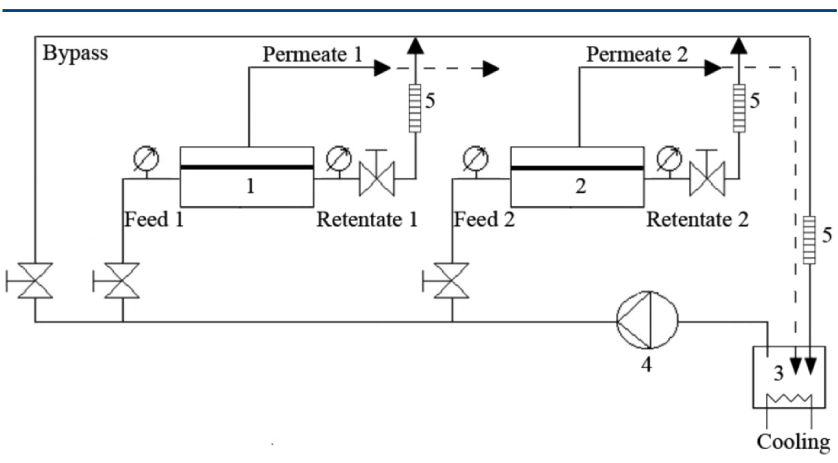

Figure 2. Schematic representation of the cross-flow NF unit (Amafilter, The Netherlands). Legend: (1) module 1, (2) module 2, (3) feed tank, (4) pump, and (5) flow meter.

consists of two modules, containing a flat sheet membrane with an effective surface area of $41.5 \mathrm{~cm}^{2}$. The flow channel is rectangular with a hydraulic diameter of $0.43 \mathrm{~cm}$. The total channel length is $29.3 \mathrm{~cm}$. No spacer was used. The cross-flow velocity was in the range of $2.7-3.3 \mathrm{~m} \mathrm{~s}^{-1}$. This corresponds to a Reynolds number of 11 400-14200 (turbulent regime). In this way, concentration polarization could be minimized. However, the cross-flow velocity is much higher than what is typically used in spiral-wound modules in full-scale plants $(0.1-$ $\left.0.5 \mathrm{~m} \mathrm{~s}^{-1}\right){ }^{15}$ The high cross-flow velocity did not cause any deformation of the membrane coupons. The transmembrane 
pressure was kept constant at 10 bar. The temperature in all experiments was maintained at $293 \mathrm{~K}$ (by a cooling water circuit). The permeate was collected in a separate tank and discarded, while the retentate was recycled to the feed tank. The filtration was stopped when a water recovery of $78 \%$ was reached, i.e., until the volume of the feed solution was reduced to $22 \%$ of its initial value. The remaining retentate solution was used for further experiments. This figure is similar to the operational conditions in full-scale NF plants, where drinking water is produced at water recoveries of $75 \%-85 \%$. $^{3}$

2.2. Ozone Reactor. Three liters of retentate solution was kept in a glass reactor vessel that had an inner diameter of 160 $\mathrm{mm}$. All solutions were ozonated at room temperature. The $\mathrm{O}_{3}-\mathrm{O}_{2}$ mixture was introduced from the bottom of the reactor, through a porous fine-bubble Pyrex diffuser. The rotation of a magnetic stirrer at the bottom of the reactor improved the mixing of the aqueous solution. The feed gas to the $\mathrm{O}_{3}$ generator (Model OZ 500, Fischer, USA) was pure $\mathrm{O}_{2}$. The gas flow rate was fixed at $60.0 \mathrm{~L} \mathrm{~h}^{-1}$ at standard temperature and pressure (STP). A gFFOZ Process Ozone Sensor (IN USA, USA) measured the $\mathrm{O}_{3}$ concentration in the gas flow entering the aqueous solution, by $\mathrm{UV}$ absorption at $254 \mathrm{~nm}$. The $\mathrm{O}_{3}$ concentration in the gas phase was kept constant (12.4 $\mathrm{mg} \mathrm{L}^{-1} \mathrm{O}_{3} ; 5.78 \times 10^{-3}$ atm (STP)). The $\mathrm{O}_{3}$ concentration in the aqueous phase was monitored with an electrochemical sensor (i.e., Model Orbisphere 3660, Orbisphere, The Netherlands).

2.3. The Decomposition of NOM and Its Kinetics. The direct reaction between $\mathrm{O}_{3}$ and NOM can be simplified in the following way: ${ }^{16-18}$

$$
\mathrm{O}_{3}+\mathrm{NOM} \rightarrow \mathrm{P}
$$

Literature data show that the reaction order for both $\mathrm{O}_{3}$ and its coreactant is 1 for the ozonation of all types of organic compounds. $^{19,20}$ It is assumed that this also holds for the reaction between $\mathrm{O}_{3}$ and NOM. ${ }^{18,21,22}$ Thus, the chemical reaction rate for the disappearance of $\mathrm{NOM}$ is

$$
\frac{\mathrm{d} C_{\mathrm{NOM}}}{\mathrm{d} t}=-k_{\mathrm{app}} C_{\mathrm{O}_{3}} C_{\mathrm{NOM}}
$$

where $k_{\text {app }}$ is the apparent rate constant between $\mathrm{O}_{3}$ and NOM. $k_{\text {app }}$ can be considered as

$$
k_{\mathrm{app}}=\frac{\sum k_{i} C_{i}}{C_{\mathrm{NOM}}}
$$

$k_{i}$ is the rate constant between $\mathrm{O}_{3}$ and the functional group $i$ that is present in the NOM with a concentration $C_{i}$.

The rate constant for the direct reaction of $\mathrm{O}_{3}$ with $\mathrm{NOM}$ shows the best correlation with the UV absorbance at 254 nm. ${ }^{23-25} \pi-\pi^{*}$ transitions of electrons in unsaturated bonds occur at this wavelength, but also between $270 \mathrm{~nm}$ and 280 nm. ${ }^{26}$ Therefore, the application of spectrophotometric measurements at a wavelength of $254 \mathrm{~nm}$ as well as $275 \mathrm{~nm}$ is suitable for describing unsaturated $\mathrm{C}-\mathrm{C}$ bonds. The UV absorbance was measured by a Model UV-1601 double beam spectrophotometer (Shimadzu, Japan).

The dimension of the UV absorbance is $\mathrm{m}^{-1}$. However, the NOM concentration should be expressed in mol (carbon) $\mathrm{m}^{-3}$ (or $\mathrm{mg} \mathrm{L}^{-1}$, in which $1 \mathrm{~mol} \mathrm{~m}^{-3}=12 \mathrm{mg} \mathrm{L}^{-1}$ ). The specific UV absorbance (SUVA) is the ratio of the UV absorbance to the dissolved organic carbon (DOC) value of the water sample. The values of SUVA at $254 \mathrm{~nm}$ are widely used and provide a specific insight into the nature of NOM. As a general rule, natural waters with high SUVA values $\left(>4 \mathrm{~L} \mathrm{mg}^{-1} \mathrm{~m}^{-1}\right)$ have a relatively high content of macromolecules rich in aromatics, whereas waters with low SUVA values $\left(<2 \mathrm{~L} \mathrm{mg}^{-1} \mathrm{~m}^{-1}\right)$ contain predominantly low molecular mass compounds, poor in aromatics. $^{26}$ The UV absorbance of the NF retentate solutions at $254 \mathrm{~nm}\left(27.67 \pm 3.89 \mathrm{~m}^{-1}\right)$ was divided by an assumed SUVA value ${ }^{1}$ of $2.22 \mathrm{~L} \mathrm{mg}^{-1} \mathrm{~m}^{-1}$ in order to compute the DOC value of $12.5 \mathrm{mg} \mathrm{L}^{-1}=1.04 \mathrm{~mol} \mathrm{~m}^{-3}$. Therefore, it is assumed that the initial NOM concentration in the NF retentate stream is $1.04 \mathrm{~mol} \mathrm{~m}^{-3}$ and that

$$
C_{\mathrm{NOM}}(t)=\frac{A(t)}{A(0)} \times\left(1.04 \mathrm{~mol} \mathrm{~m}^{-3}\right)
$$

where $A$ is the UV absorbance of the NF retentate at $275 \mathrm{~nm}$.

2.4. Economic Assessment. The economic evaluation of the integrated process where $\mathrm{NF}$ and $\mathrm{O}_{3}$ oxidation are combined (see Figure 1) should take into account the initial capital costs and the maintenance costs. All values are expressed in euros $(€)$. An exchange rate of $1 €=1.30$ US\$ is assumed for literature data found in U.S. dollars. All items are adjusted for inflation to represent 2011 values, using the CPI (consumer price index) inflation calculator. ${ }^{27}$ The loans to cover the investment costs are paid back in equal annual parts and the annual interest rate is $6 \%$. The total number of operating hours is 8000 per year.

2.4.1. NF Unit. The design flow rate of the NF unit is represented by $F\left[\mathrm{~m}^{3} \mathrm{~h}^{-1}\right]$ and the total membrane area is $A$ $\left[\mathrm{m}^{2}\right]$. The following equations are based on the data of Van der Bruggen et al. ${ }^{28}$

Capital costs:

- Civil investment costs (buildings where the installation is housed): $1350 F+64.6 A$. Depreciation period for these investments is 30 years.

- Mechanical investment costs (pumps, filters, piping, etc.): $5640 F^{0.85}+47.4 A$. Depreciation period is 15 years.

- Electrotechnical investment costs (energy supply (e.g., transformators), control equipment and all electronic components): $2190000+2.815 F \Delta P . \Delta P$ is the applied pressure across the membranes [bar].

- Purchase costs of membranes: $80 \mathrm{~A}$. This loan is paid back in 30 years.

Maintenance costs:

- Energy costs: the installation consumes $0.040 \mathrm{kWh}$ per $\mathrm{m}^{3}$ feed per bar feed pressure. The electricity cost is assumed to be $0.0762 € / \mathrm{kWh}$ (estimation based on local costs of utilities in The Netherlands). ${ }^{29}$

- Membrane replacement costs: the membrane lifetime is estimated at 4 years, so $25 \%$ of the membranes need to be replaced annually.

- Chemical costs: cost of chemicals is $0.030 €$ per $\mathrm{m}^{3}$ feed.

- Replacement of miscellaneous parts: annually $2 \%$ of the total investment costs.

2.4.2. $\mathrm{O}_{3}$ Oxidation Unit.

Capital costs:

- $\mathrm{O}_{3}$ generator: a generator with a capacity of $8.50 \mathrm{~kg} \mathrm{O}$ $\mathrm{h}^{-1}$ can be purchased for $375000 €$. The expected lifetime of the generator is 20 years (= depreciation time). ${ }^{30}$

- Contacting equipment: $1224 V_{\mathrm{r}}$, in which $V_{\mathrm{r}}$ is the volume of the $\mathrm{O}_{3}$ reactor $\left[\mathrm{m}^{3}\right]$. $^{31}$ This equation is 
applicable for reactor volumes between $3.2 \mathrm{~m}^{3}$ and 51.3 $\mathrm{m}^{3}$.

Maintenance costs:

- $\mathrm{O}_{3}$ generator: the required power and $\mathrm{O}_{2}$ consumption will be calculated in section 3.2. The electricity costs and the purchase costs of $\mathrm{O}_{2}$ are assumed to be 0.0762 $€ / \mathrm{kWh}$ and $60.96 € /$ ton $\mathrm{O}_{2}$, respectively (estimation based on local costs of utilities in The Netherlands). ${ }^{29}$

- Replacement of miscellaneous parts: annually $1 \%$ of the total investment costs.

\section{RESULTS AND DISCUSSION}

3.1. Determination of the Kinetic Regime. 3.1.1. Calculation of the Diffusion Coefficients. Diffusion coefficients of compounds in water can be determined from different empirical correlations. ${ }^{32}$ The concentration of the dissolved species in the retentate stream is very small $\left(\sim 1 \mathrm{~g} \mathrm{~L}^{-1}\right)$, so that the diffusion coefficients at infinite dilution can be used. The Stokes-Einstein equation is a purely theoretical method for estimating $D_{1}$, i.e., the binary diffusion coefficient of solute 1 in water $\left[\mathrm{m}^{2} \mathrm{~s}^{-1}\right]$ :

$$
D_{1}=\frac{k_{\mathrm{B}} T}{3 \pi \mu_{2} d_{1}}
$$

$k_{\mathrm{B}}$ is the Boltzmann constant $\left(k_{\mathrm{B}}=1.38 \times 10^{-23} \mathrm{~m}^{2} \mathrm{~kg} \mathrm{~s}^{-2}\right.$ $\left.\mathrm{K}^{-1}\right), \mu_{2}$ the dynamic viscosity of water $\left[10^{-3} \mathrm{~Pa} s\right.$ at $\left.293 \mathrm{~K}\right]$, and $d_{1}$ the hydrated diameter of the diffusing molecule [m]. The relationship is valid only if the molecules of the diffusing species are very large, compared to the water molecules. ${ }^{33}$

The equation of Wilke and Chang ${ }^{34}$ is a well-known semiempirical correlation for the calculation of $D_{1}$ :

$$
D_{1}=7.4 \times 10^{-12}\left(\frac{\sqrt{\phi_{2} M_{2}} T}{\mu_{2} V_{1}^{0.6}}\right)
$$

$\phi_{2}$ is the association factor for water $\left(\phi_{2}=2.26\right),{ }^{35} M_{i}$ the molecular mass of species $i\left[\mathrm{~g} \mathrm{~mol}^{-1}\right]$, and $V_{i}$ the molar volume of species $i$ at its normal boiling point $\left[\mathrm{cm}^{3} \mathrm{~mol}^{-1}\right]$. The use of the Wilke and Chang equation in aqueous systems leads to an average error of $\sim 10 \%-15 \%{ }^{21}$ Since the equation is not dimensionally consistent, the specified units must be employed. Other correlations similar to that of Wilke and Chang can also be used to determine the diffusion coefficient: King et al., ${ }^{36}$ Hayduk and Laudi, ${ }^{35}$ Nakanishi, ${ }^{37}$ Hayduk and Minhas, ${ }^{38}$ and Siddiqi and Lucas. ${ }^{39}$ For the specific case of $\mathrm{O}_{3}$ as the solute, some other empirical correlations are available, such as Matrozov et al. ${ }^{40}$ and Johnson and Davis. ${ }^{41}$ All these correlations are listed in Table 2.

The diffusion coefficient of $\mathrm{O}_{3}$ is calculated with the help of these correlations and the computed values are listed in Table 3. The estimated values for $D_{\mathrm{O}_{3}}$ range between $11.7 \times 10^{-10} \mathrm{~m}^{2}$ $\mathrm{s}^{-1}$ and $17.7 \times 10^{-10} \mathrm{~m}^{2} \mathrm{~s}^{-1}$. The diffusion coefficient of $\mathrm{O}_{3}$ is set equal to the average of these estimated values, i.e., (15.0 \pm 1.2) $\times 10^{-10} \mathrm{~m}^{2} \mathrm{~s}^{-1}$.

The diffusion coefficient of NOM is calculated mainly from the Wilke and Chang equation, because NOM molecules are large, compared to the water molecules $(0.2 \mathrm{~nm})$, fulfilling the requirement for using this correlation. One peculiar problem when using this equation is the determination of the hydrodynamic diameter of the NOM molecules. This is the diameter of a sphere having the same hydrodynamic properties
Table 2. Correlations for the Diffusion Coefficient $D_{1}$ of Species 1 in Water (Species 2) at Infinite Dilution $\left[\mathrm{m}^{2} \mathrm{~s}^{-1}\right]^{a}$

\begin{tabular}{ll}
$\quad$ reference & \multicolumn{1}{c}{ expression } \\
$\begin{array}{c}\text { Hayduk and } \\
\text { Laudie }^{35}\end{array}$ & $D_{1}=13.26 \times 10^{-9}\left(\frac{1}{\mu_{2}^{1.14} V_{1}^{0.589}}\right)$ \\
$\begin{array}{c}\text { Hayduk and } \\
\text { Minhas }{ }^{38}\end{array}$ & $D_{1}=1.25 \times 10^{-12}\left(V_{1}^{-0.19}-0.292\right) \mu_{2}^{\left(9.58 / V_{1}\right)-1.12} T^{1.52}$ \\
$\begin{array}{c}\text { Johnson and } \\
\text { Davis }\end{array}{ }^{41 b}$ & $D_{1}=5.9 \times 10^{-12}\left(\frac{T}{\mu_{2}}\right)$ \\
King et al. $^{36}$ & $D_{1}=4.4 \times 10^{-12} \frac{\left(V_{2} / V_{1}\right)^{1 / 6}\left(\Delta H_{2} / \Delta H_{1}\right)^{1 / 2} T}{\mu_{2}}$ \\
Matrozov et al. $^{40 b}$ & $D_{1}=4.27 \times 10^{-12}\left(\frac{T}{\mu_{2}}\right)$ \\
Nakanishi $^{37}$ & $D_{1}=10^{-9}\left(\frac{2.9726}{\mu_{2} V_{1}^{1 / 3}}+\frac{0.716 \phi_{2} V_{2}}{\mu_{2} V_{1}}\right)$ \\
Siddiqi and $_{\text {Lucas }^{39}}$ & $D_{1}=9.89 \times 10^{-12}\left(\frac{V_{2}^{0.265} T}{V_{1}^{0.45} \mu_{2}^{0.907}}\right)$
\end{tabular}

${ }^{a}$ Notations and units: $V$ is the molar volume at the normal boiling point $\left[\mathrm{cm}^{3} \mathrm{~mol}^{-1}\right], \Delta H$ the latent heat of vaporization at the normal boiling point [any consistent units], $T$ the temperature $(T=293 \mathrm{~K}), \mu$ the dynamic viscosity $\left[\mathrm{cP}=10^{-3} \mathrm{~Pa} \mathrm{~s}\right]$, and $\varphi$ the association factor $(\varphi$ $=2.26$ for water). ${ }^{b}$ This correlation can only be used for $\mathrm{O}_{3}$ as solute (species 1).

Table 3. Calculated Values for the Diffusion Coefficient of $\mathrm{O}_{3}$ in Water at $293 \mathrm{~K}$. The equations of the used correlations can be found in Table 2. The molar volume and the heat of vaporization of $\mathrm{O}_{3}$ is $35.50 \mathrm{~cm}^{3} \mathrm{~mol}^{-1}\left(\mathrm{Medard}^{55}\right.$ ) and 15.18 $\mathrm{kJ} \mathrm{mol}^{-1}$ (Perry and Green ${ }^{47}$ ), respectively. The viscosity of

\begin{tabular}{|c|c|}
\hline Reference & $D_{\mathrm{O}_{3}}\left(\times 10^{-10} \mathrm{~m}^{2} \mathrm{~s}^{-1}\right)$ \\
\hline Hayduk and Laudie ${ }^{35}$ & 16.2 \\
\hline Hayduk and Minhas ${ }^{38}$ & 13.6 \\
\hline Johnson and Davis ${ }^{41}$ & 16.1 \\
\hline King et al. ${ }^{36}$ & 17.7 \\
\hline Matrozov et al. ${ }^{40}$ & 11.7 \\
\hline Nakanishi $^{37}$ & 17.6 \\
\hline Siddiqi and Lucas ${ }^{39}$ & 11.8 \\
\hline Wilke and Chang ${ }^{34}$ & 15.1 \\
\hline average value & $15.0 \pm 1.2$ \\
\hline
\end{tabular}
water is $1 \mathrm{cP}$ at $293 \mathrm{~K}$

as the actual particle in Brownian diffusion. Thorsen ${ }^{42}$ proposed the following equation for the hydrodynamic diameter of NOM particles:

$$
\begin{aligned}
d_{1}= & (0.88 \mathrm{~nm})\left[0.85\left(\frac{M_{\mathrm{NOM}}}{200 \mathrm{~g} \mathrm{~mol}^{-1}}\right)^{1 / 3}\right. \\
& \left.+0.15\left(\frac{M_{\mathrm{NOM}}}{200 \mathrm{~g} \mathrm{~mol}^{-1}}\right)^{5 / 6}\right]
\end{aligned}
$$

However, the molecular mass of NOM is not a fixed number, but NOM does have a continuous mass distribution. The value of $d_{1}$ should be weighted by the molecular mass distribution of the NOM. The results of Her et al. ${ }^{43}$ for the Barr-Lake surface water (see Figure $6 \mathrm{~b}$ in that article) are representative for other surface waters and are used in the following calculation. Only the molecular mass distribution between $610 \mathrm{~g} \mathrm{~mol}^{-1}$ and 3680 $\mathrm{g} \mathrm{mol}^{-1}$ was considered, because that part comprises most of the UV-absorbing compounds, i.e., the NOM fraction that is the most reactive to $\mathrm{O}_{3} .{ }^{5,17}$ The size exclusion chromatogram 
with a DOC detector for Barr-Lake water between 610 and $3680 \mathrm{~g} \mathrm{~mol}^{-1}$ was normalized and fitted by a cubic spline curve $S(x)$ with natural end points, ${ }^{44}$ in which $x={ }^{10} \log \left(M_{\mathrm{NOM}}\right)$ (because the chromatogram has a logarithmic abscissa). The weighted average of the hydrodynamic diameter of NOM is then calculated by the following expression:

$$
\bar{d}_{1}=\frac{\int_{610}^{3680} d_{1}\left(M_{\mathrm{NOM}}\right) S\left({ }^{10} \log M_{\mathrm{NOM}}\right) \mathrm{d} M_{\mathrm{NOM}}}{3680-610}
$$

This results in $\bar{d}_{1}=2.95 \mathrm{~nm}$, so that the hydrodynamic diameter of the NOM molecules is more than 10 times larger than the size of water molecules. The use of the Wilke and Chang equation is thus justified, and this results in $D_{\mathrm{NOM}}=1.45$ $\times 10^{-10} \mathrm{~m}^{2} \mathrm{~s}^{-1}$.

3.1.2. The Solubility of $\mathrm{O}_{3}$ in Pure Water. The dissolved $\mathrm{O}_{3}$ concentration, as a function of time in pure water buffered at $\mathrm{pH} \mathrm{7,} \mathrm{is} \mathrm{shown} \mathrm{in} \mathrm{Figure} \mathrm{(3a).} \mathrm{After} \mathrm{a} \mathrm{lag} \mathrm{of} \sim 20 \mathrm{~s}$, the

(a)

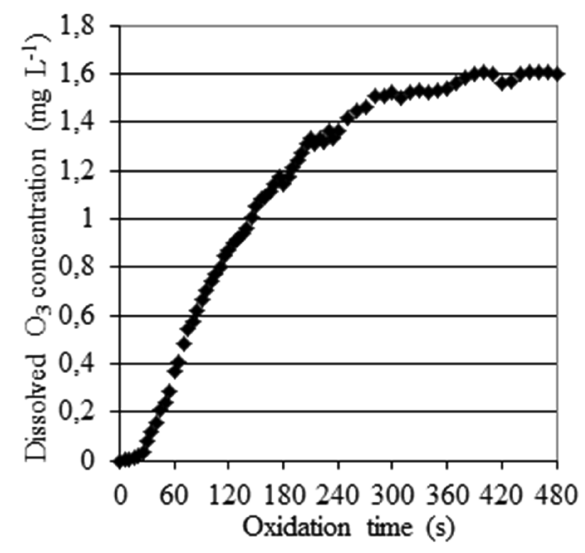

(b)

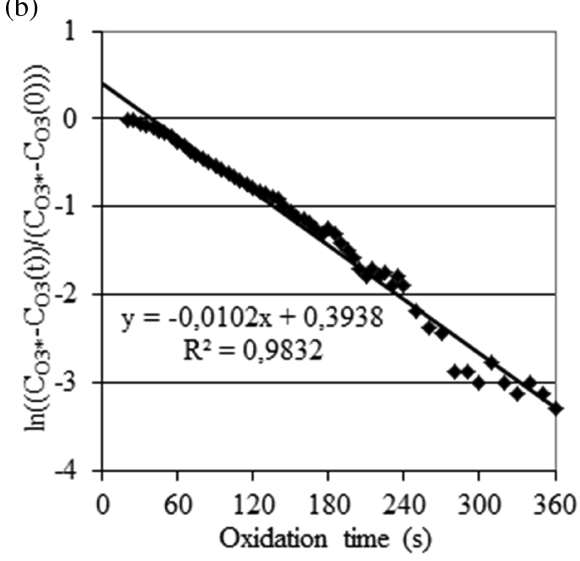

Figure 3. (a) Dissolved $\mathrm{O}_{3}$ concentration in pure water at $\mathrm{pH}$ 7. The $\mathrm{O}_{3}$ concentration in the gas phase was kept constant at $12.4 \mathrm{mg} \mathrm{O}_{3} \mathrm{~L}^{-1}$ (STP). (b) The data in Figure 3 a could be fitted by a straight line if the vertical axis is transformed to $\ln \left(\left(C_{\mathrm{O}_{3}}^{\infty}-C_{\mathrm{O}_{3}}(t)\right) /\left(C_{\mathrm{O}_{3}}^{\infty}-C_{\mathrm{O}_{3}}(0)\right)\right)$.

concentration of $\mathrm{O}_{3}$ steadily increases until it reaches a constant value of $1.60 \mathrm{mg} \mathrm{L}^{-1}$ after $380 \mathrm{~s}$. The pseudo-Henry constant $H^{*}$ can be calculated from this plateau value, $C_{\mathrm{O}_{3}}^{\infty}$, using eq $\mathrm{S} 4$ in the Supporting Information, if $\mathrm{C}_{\mathrm{O}_{3}}^{\infty}=C_{\mathrm{O}_{3}}^{*}$ (the decomposition rate of $\mathrm{O}_{3}$ is negligible, compared to the mass transfer rate). The justification of this assumption will be given in section 3.1.3. The calculated value of the Henry constant for $\mathrm{O}_{3}$ in

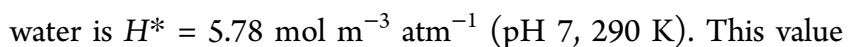
lies within the range 3-7 $\mathrm{mol} \mathrm{m}^{-3} \mathrm{~atm}^{-1}$, reported by De Smedt et al. $^{45}$ for a $\mathrm{pH}$ value between 6.5 and 7.5 at $289 \mathrm{~K}$.

In order to calculate $k_{L} a$, the help variable $\ln \left[\left(C_{\mathrm{O}_{3}}^{\infty}-C_{\mathrm{O}_{3}}(t)\right) /\right.$ $\left.\left(C_{\mathrm{O}_{3}}^{\infty}-C_{\mathrm{O}_{3}}(0)\right)\right]$ was introduced, and its values between 20 and $360 \mathrm{~s}$ are shown in Figure 3b. According to eq S21 in the Supporting Information, this should be a straight line through the origin with slope $-\left[k_{L} a+k_{d}(1-\varepsilon)\right] /(1-\varepsilon)$. The absolute value of the slope of this straight line is $0.0102 \pm 0.0010 \mathrm{~s}^{-1} \cdot k_{d}$ is set equal to $(8.67 \pm 2.35) \times 10^{-4} \mathrm{~s}^{-1}$ at $\mathrm{pH} 7$ (see Table S1 in the Supporting Information). The gas holdup $\varepsilon$ is determined by eq $\mathrm{S} 6$ in the Supporting Information. For a gas flow of $60.0 \mathrm{~L} \mathrm{~h}^{-1}: h_{\mathrm{L}+\mathrm{G}}=14.3 \mathrm{~cm}$ and $h_{\mathrm{L}}=13.7 \mathrm{~cm}$ (three observations), so that $\varepsilon=0.04$. The value of $k_{L} a$ is thus 0.0089 $\pm 0.0010 \mathrm{~s}^{-1}$. The regression line in Figure $3 \mathrm{~b}$ does not cross the horizontal axis in the origin, but it does cross at $t=39 \mathrm{~s}$. This lag period is due to the response time of the $\mathrm{O}_{3}$ sensor. The deviation between the observed values of $\ln \left[\left(C_{\mathrm{O}_{3}}^{\infty}\right.\right.$ $\left.\left.-C_{\mathrm{O}_{3}}(t)\right) /\left(C_{\mathrm{O}_{3}}^{\infty}-C_{\mathrm{O}_{3}}(0)\right)\right]$ and the regression line is higher at the far right of the curve in Figure $3 b$, because of the very steep slope of the logarithmic function for $x \rightarrow 0+$.

The specific interfacial area $a$ is calculated from eq S5 in the Supporting Information. To do this, the mean diameter of the gas bubbles should be known. It was estimated by visual inspection of a photograph of the bubble cloud in the $\mathrm{O}_{3}$ reactor: $d_{b}=2 \mathrm{~mm}$. The calculation of the value for $a$ results in $120 \mathrm{~m}^{-1}$. This agrees with typical values of $a$ for gas diffusers (with mechanical mixing), ranging from $30 \mathrm{~m}^{-1}$ to $500 \mathrm{~m}^{-1}$, according to Benefield et al., ${ }^{46}$ and between $50 \mathrm{~m}^{-1}$ and 600 $\mathrm{m}^{-1}$, according to Perry and Green. ${ }^{47}$ The liquid-phase masstransfer coefficient $\left(k_{L}\right)$ cannot be determined experimentally, but is calculated by dividing $k_{L} a$ by $a: k_{L}=7.4 \times 10^{-4} \mathrm{~m} \mathrm{~s}^{-1}$. This value lies somewhat above the range given by Perry and Green, ${ }^{47}$ i.e., $(1-4) \times 10^{-4} \mathrm{~m} \mathrm{~s}^{-1}$, but is acceptable in view of the uncertainty on the value of $a$.

3.1.3. The Hatta Number for the Decomposition of $\mathrm{O}_{3}$ in Pure Water. In order to determine the pseudo-Henry constant, it was assumed that $C_{\mathrm{O}_{3}}^{*}=C_{\mathrm{O}_{3}}^{\infty}$. The validity of this assumption is investigated by calculating $C_{\mathrm{O}_{3}}^{\infty}$ from eq $\mathrm{S} 17$ in the Supporting Information and comparing it with $C_{\mathrm{O}_{3}}^{*}$. If $k_{d}$ is set equal to $(8.67 \pm 2.35) \times 10^{-4} \mathrm{~s}^{-1}$ at $\mathrm{pH} 7$ (see Table $\mathrm{S} 1$ in the Supporting Information), then $M_{H 1}=0.00153$ (see eq $S 15$ in the Supporting Information). The low value of $M_{H 1}$ indicates that the kinetic regime of $\mathrm{O}_{3}$ decomposition in pure water corresponds to a very slow reaction $\left(M_{H}<0.03\right),{ }^{21}$ and hence the concentration profile of $\mathrm{O}_{3}$ is nearly uniform throughout the film layer (see eq S14 in the Supporting Information). The concentration of $\mathrm{O}_{3}$ in the bulk liquid is almost equal to the $\mathrm{O}_{3}$ concentration at the gas/liquid interface: $C_{\mathrm{O}_{3}}^{\infty}=0.0330 \mathrm{~mol} \mathrm{~m}^{-3}$ versus $C_{\mathrm{O}_{3}}^{*}=0.0333 \mathrm{~mol} \mathrm{~m} \mathrm{~m}^{-3}$. This justifies the kinetic treatment in section 3.1.2 to determine the pseudo-Henry constant.

3.1.4. Apparent Reaction Rate Constant between $\mathrm{O}_{3}$ and NOM. The residence time of the solution in the $\mathrm{O}_{3}$ reactor ranges from $2 \mathrm{~min}$ to $20 \mathrm{~min}$ in large-scale applications, so that only this period will be investigated in the following discussion. The concentration of dissolved $\mathrm{O}_{3}$ was lower than $0.020 \mathrm{mg}$ $\mathrm{L}^{-1}$ in the bulk of the liquid phase throughout the first $20 \mathrm{~min}$ of the experiment (see Figure 5 in the work of Van Geluwe et al. $\left.{ }^{6}\right)$. The value of the apparent reaction constant $k_{\text {app }}$ between 
$\mathrm{O}_{3}$ and NOM is calculated by solving the system of eqs 9 and 10:

- First, a mass balance is set up for the agitated batch tank used in the laboratory-scale experiments. At any instant, the rate of the decrease of the NOM concentration in the liquid is equal to the absorption rate of $\mathrm{O}_{3}$ (quasi steadystate approximation):

$$
-(1-\varepsilon) V_{\mathrm{r}} \frac{\mathrm{d} C_{\mathrm{NOM}}}{\mathrm{d} t}=-r_{\mathrm{O}_{3}} V_{r}
$$

$V_{\mathrm{r}}$ is the volume of the laboratory-scale reactor $\left[\mathrm{m}^{3}\right] . C_{\mathrm{NOM}}$ was calculated according to the data of Van Geluwe et al. $^{6}$ (see Figure 3 in that article) by eq 4 . The derivative $\left(\mathrm{d} C_{\mathrm{NOM}}\right) /(\mathrm{d} t)$ was approximated numerically by central differences (with the exception of the derivative at $t=0$, for which a forward difference formula was used). ${ }^{44}$

- Second, assume that $M_{H}<0.3$ (slow reaction with respect to mass transfer), ${ }^{21}$ so that $E \approx 1$. According to eq $S 8$ in the Supporting Information, the overall rate of $\mathrm{O}_{3}$ consumption is then equal to

$$
-r_{\mathrm{O}_{3}}=\frac{k_{L} a k_{\mathrm{app}} C_{\mathrm{NOM}}(1-\varepsilon)}{k_{L} a+k_{\mathrm{app}} C_{\mathrm{NOM}}(1-\varepsilon)} C_{\mathrm{O}_{3}}^{*}
$$

The apparent rate constant $k_{\text {app }}$, as a function of the oxidation time, is shown in Figure 4. The apparent rate constant is not a

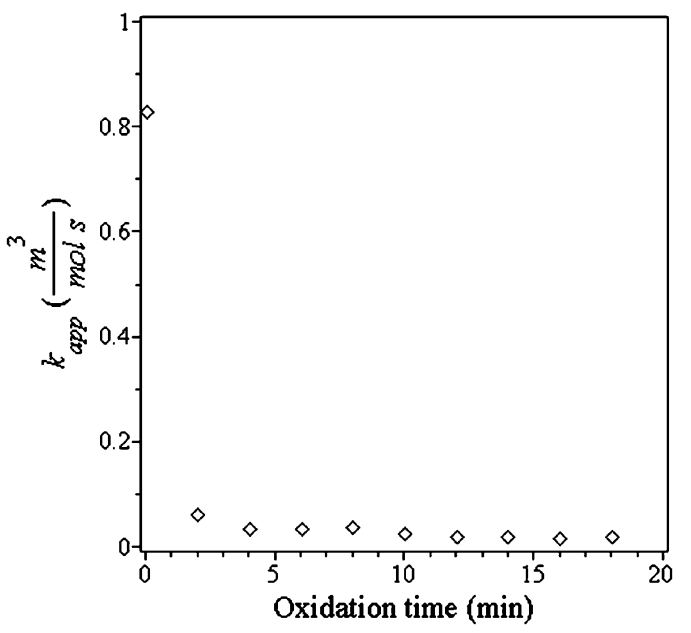

Figure 4. Apparent rate constant $\left(k_{\text {app }}\right)$ for the reaction between $\mathrm{NOM}$ and $\mathrm{O}_{3}$, as a function of the oxidation time.

constant: it decreases at higher oxidation times. At the start of the experiment, $k_{\text {app }}$ has a value of $0.830 \mathrm{~m}^{3} \mathrm{~mol}^{-1} \mathrm{~s}^{-1}$, but after $2 \mathrm{~min}$, its value has decreased to $0.063 \mathrm{~m}^{3} \mathrm{~mol}^{-1} \mathrm{~s}^{-1}$. It subsequently reaches a fairly constant value of $0.036 \mathrm{~m}^{3} \mathrm{~mol}^{-1}$ $\mathrm{s}^{-1}$, after which it again decreases to a second plateau $\left(0.018 \mathrm{~m}^{3}\right.$ $\mathrm{mol}^{-1} \mathrm{~s}^{-1}$ ). Note that these values (except for $k_{\text {app }}$ at $t=0$ ) are in agreement with those reported in the literature, which range from 0.0132 to $0.0954 \mathrm{~m}^{3} \mathrm{~mol}^{-1} \mathrm{~s}^{-1}$ (see section $\mathrm{S} .3$ in the Supporting Information). The evolution of $k_{\text {app }}$ is caused by the change of the chemical composition and conformation of the NOM. $^{48,49}$ It is not unexpected that the reaction rate is higher at the beginning of the ozonation experiment, since the easily oxidizable species can react now rapidly with $\mathrm{O}_{3} .{ }^{18,50}$

3.1.5. The Hatta number and the Enhancement Factor for the Reaction between $\mathrm{O}_{3}$ and NOM. When the apparent rate constant $k_{\text {app }}$ is known, the Hatta number $M_{H}$ can subsequently be calculated (see eq S10 in the Supporting Information), as a function of the oxidation time, as shown in Figure 5. The

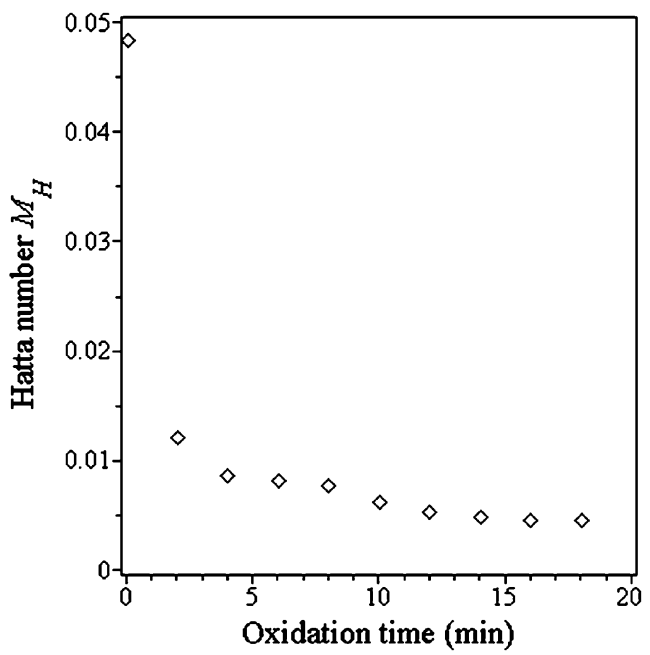

Figure 5. Hatta number $M_{H}$, as a function of the oxidation time.

results show that the Hatta number ranges from 0.0484 to 0.0045 . Consequently, the kinetic regime of the reactions between $\mathrm{NOM}$ and $\mathrm{O}_{3}$ is slow $\left(M_{H}<0.3\right)$ and the reactions occur only in the bulk liquid, not in the liquid film. $M_{H}$ is also a monotonously decreasing function and its value is 3-30 times higher than the Hatta number for $\mathrm{O}_{3}$ decay in pure water $\left(M_{H 1}\right.$ $=0.00153)$. Thus, the decomposition reaction of $\mathrm{O}_{3}$ will not interfere with the reaction between $\mathrm{O}_{3}$ and NOM.

At low values of the Hatta number, the enhancement factor $E$ is independent of $E_{i}\left(E_{i}=8.19\right.$ at $\left.t=0\right)$. It is asymptotically equivalent to $1+\left(M_{H}{ }^{2} / 3\right)$ (see Figure $S 1$ in the Supporting Information) and does not reach values higher than 1.001. The necessary assumption for the use of eq 10 is thus valid. In case the value of $E$ is significantly different from 1 , the same procedure for the determination of $k_{\text {app }}$ and $E$ can be applied, but in an iterative way. The fact that the enhancement factor $E$ is $\sim 1$ means that the $\mathrm{O}_{3}$ fluxes for the NOM solution are very close to the fluxes for pure water. Low enhancement factors for $\mathrm{O}_{3}$ oxidation of the NOM solution are attributed to the relatively low NOM concentration $\left(\sim 1 \mathrm{~mol} \mathrm{C} \mathrm{m}^{-3}\right)$, together with the low value for the maximal amount of $\mathrm{O}_{3}$ dissolved in the liquid $\left(0.0333 \mathrm{~mol} \mathrm{~m}^{-3}\right) .^{51}$

3.2. Calculation of the Reactor Volume on an Industrial Scale. Bubble columns are commonly used as $\mathrm{O}_{3}$ contactors in water treatment, because of their simple construction, operation, and maintenance. ${ }^{21}$ Bubble columns are typically constructed with a water depth of $\sim 6 \mathrm{~m}$ to achieve $85 \%-95 \% \mathrm{O}_{3}$ transfer efficiency. ${ }^{52}$ Figure 6 shows a sketch of the reactor. $\mathrm{O}_{3}$-containing gas is introduced at the bottom of the column. The flow direction of the liquid is from top to bottom. The flow scheme assumes plug flow for both the liquid and the gas phase. Assume that the flow rate of the NF retentate is $400 \mathrm{~m}^{3} \mathrm{~h}^{-1}$. The design flow rate of the installation is $20 \%$ higher, to accommodate for peaks in the water demand: $F=480 \mathrm{~m}^{3} \mathrm{~h}^{-1}=7.41 \times 10^{-3} \mathrm{~mol} \mathrm{~s}^{-1}$.

First, the partial pressure of $\mathrm{O}_{3}$ in the inlet and outlet gas was determined. The $\mathrm{O}_{3}$ concentration in the inlet gas is a tradeoff between the energy costs of the $\mathrm{O}_{3}$ generator and the purchase costs of pure $\mathrm{O}_{2}$. Figure 7 a shows the performance characteristics of a large-scale $\mathrm{O}_{3}$ generator. ${ }^{53}$ The dotted line represents 


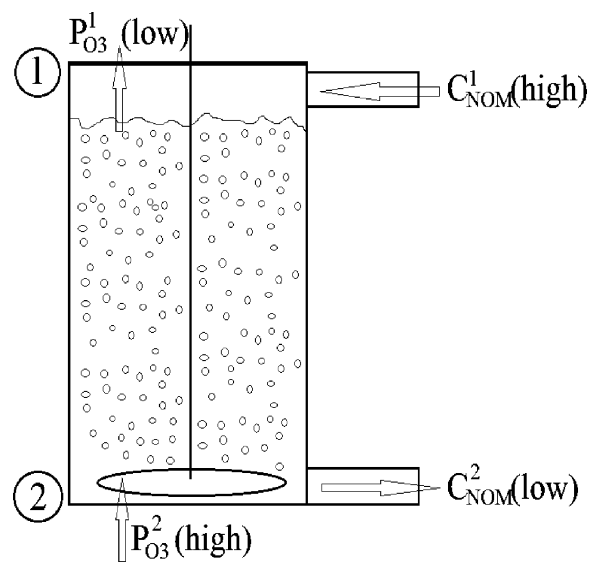

Figure 6. Sketch of the countercurrent bubble reactor.
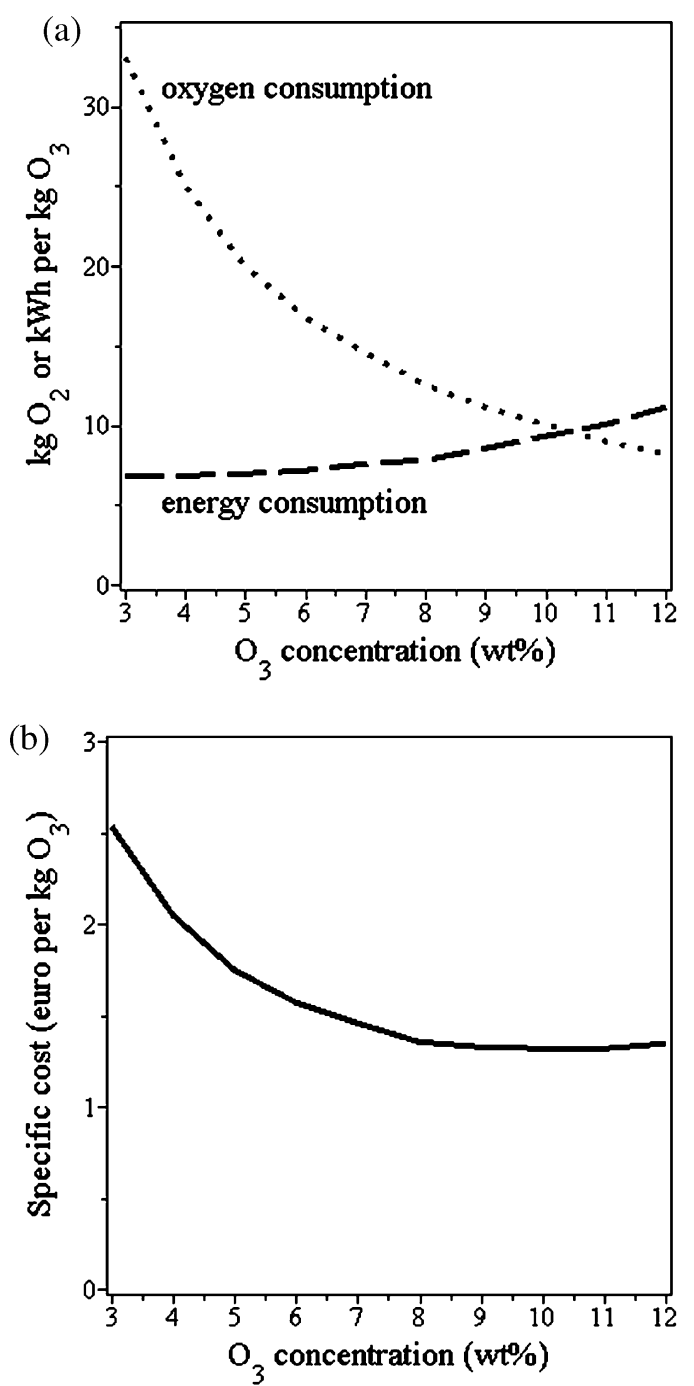

Figure 7. (a) Oxygen consumption $\left(\mathrm{kg} \mathrm{O}_{2}\right.$ per $\left.\mathrm{kg} \mathrm{O}_{3}\right)$ and energy consumption ( $\mathrm{kWh}$ per $\mathrm{kg} \mathrm{O}_{3}$ ), as a function of the $\mathrm{O}_{3}$ concentration in the gas stream after passage through the $\mathrm{O}_{3}$ generator. (Adapted from Rakness and Hunter. ${ }^{53}$.) (b) Specific cost of $\mathrm{O}_{3}$ generation as a function of the $\mathrm{O}_{3}$ concentration in the gas stream.

the $\mathrm{O}_{2}$ consumption $\left[\mathrm{kg} \mathrm{O}\right.$ per $\left.\mathrm{kg} \mathrm{O}_{3}\right]$ and the dashed line is the energy consumption $\left[\mathrm{kWh}\right.$ per $\mathrm{kg} \mathrm{O}_{3}$ ] for various $\mathrm{O}_{3}$ concentrations in the gas stream after passage through the generator. The specific cost of the generation of $\mathrm{O}_{3}$ can now be calculated, as shown in Figure $7 \mathrm{~b}$. It was assumed that the electricity cost is equal to $0.0762 €$ per $\mathrm{kWh}$ and the purchase cost of pure $\mathrm{O}_{2}$ is $60.96 €$ per ton $\mathrm{O}_{2}{ }^{29}$ Figure $7 \mathrm{~b}$ shows that there exists an optimal $\mathrm{O}_{3}$ concentration, so that the total production cost of $\mathrm{O}_{3}$ is minimal. There is a broad minimum at $\sim 10$ wt $\% \mathrm{O}_{3}$ and this corresponds to a partial pressure of 0.0685 atm $\mathrm{O}_{3}$ in the gas inlet of the reactor. The partial pressure of $\mathrm{O}_{3}$ in the outlet gas is taken to be $10 \%$ of the partial pressure in the inlet gas. The specific $\mathrm{O}_{3}$ cost then amounts to $1.3145 €$ per $\mathrm{kg} \mathrm{O}_{3}$.

The stoichiometrically required gas flow rate $G\left[\mathrm{~mol} \mathrm{~s}^{-1}\right]$ can be calculated from a mass balance over the entire column:

$$
G \frac{\left(P_{\mathrm{O}_{3}}^{2}-P_{\mathrm{O}_{3}}^{1}\right)}{1 \mathrm{~atm}}=F \frac{\left(C_{\mathrm{NOM}}^{1}-C_{\mathrm{NOM}}^{2}\right)}{55600 \mathrm{~mol} \mathrm{~m}^{-3}}
$$

The partial pressure of $\mathrm{O}_{3}$ in the inlet and outlet gas are fixed, so the gas flow rate is increased if more $\mathrm{O}_{3}$ is needed. The NOM concentration in the feed stream is fixed $\left(C_{\mathrm{NOM}}^{1}=1.04\right.$ mol $\left.\mathrm{m}^{-3}\right)$ and the reactor volume $V_{r}\left[\mathrm{~m}^{3}\right]$ is calculated for different values of the outlet concentration of $\operatorname{NOM}\left(C_{\mathrm{NOM}}^{2}\right)$ by the following equation:

$$
V_{\mathrm{r}}=\frac{G}{1 \mathrm{~atm}} \int_{P_{\mathrm{O}_{3}}^{1}}^{P_{\mathrm{O}_{3}}^{2}}\left(\frac{d P_{\mathrm{O}_{3}}}{-r_{\mathrm{O}_{3}}}\right)
$$

where $-r_{\mathrm{O}_{3}}$ is calculated by eq $\mathrm{S} 8$ in the Supporting Information. The term $-r_{\mathrm{O}_{3}}$ depends on $P_{\mathrm{O}_{3}}, C_{\mathrm{NOM}}, k_{\mathrm{app}}, k_{\mathrm{L}} a$, and $E$. Assume that the value of $k_{L} a$ of the bubble diffuser is the same as for the laboratory-scale equipment. The value of $P_{\mathrm{O}_{3}}$ and $C_{\mathrm{NOM}}$ can be calculated at various places in the reactor by applying eq 11 from point 1 to point $i$ in the reactor, in which the value of $k_{\text {app }}$ depends on $C_{\mathrm{NOM}}$. The value of the enhancement factor $E$ is $\sim 1$ at every point in the reactor.

The reactor volume can be calculated by approximating the integral in eq 12, using the trapezoidal rule. ${ }^{44}$ The results are shown in Figure 8, and the specific $\mathrm{O}_{3}$ consumption is shown in Figure 9. The reactor volume increases from $8.2 \mathrm{~m}^{3}$ for a decrease of the UV absorbance of the NOM by $26 \%$, to $27.6 \mathrm{~m}^{3}$ for a decrease of the UV absorbance of the NOM by $60 \%$. A higher NOM removal also implies that the gas flow must increase, and thus the specific $\mathrm{O}_{3}$ consumption, which ranges

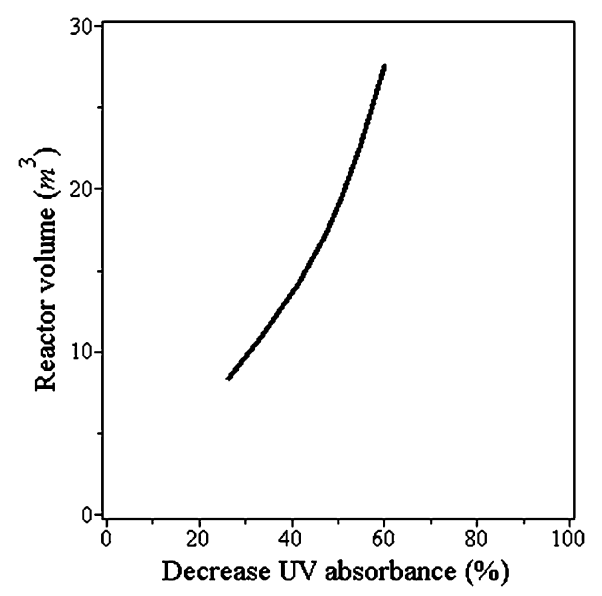

Figure 8. Required reactor volume as a function of the NOM removal (measured by the decrease in UV absorbance at $275 \mathrm{~nm}$ ). 


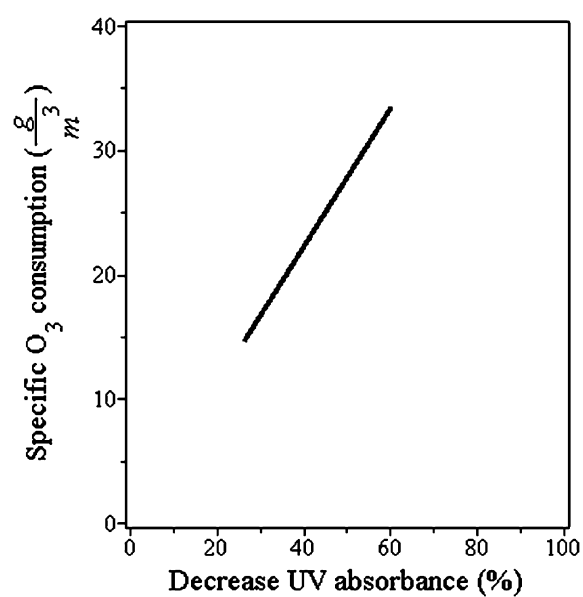

Figure 9. Specific $\mathrm{O}_{3}$ consumption (averaged over the entire reactor volume), as a function of the NOM removal (measured by the decrease in UV absorbance at $275 \mathrm{~nm}$ ).

from 14.6 to $33.5 \mathrm{~g} \mathrm{O}_{3}$ per $\mathrm{m}^{3}$ retentate stream. The specific $\mathrm{O}_{3}$ consumption increases linearly at higher NOM removal, because it was assumed that the stoichiometry of the reaction between $\mathrm{O}_{3}$ and NOM (eq 1) remains constant.

3.3. Water Recovery of the Second NF Module. The recovery that can be achieved in the second NF module is estimated from the relative membrane permeabilities shown in Table 1. At the maximal recovery of the second NF module, the retentate obtained in this module (treated by $\mathrm{O}_{3}$ ) fouls the membranes as severely as the retentate obtained in the first NF module (not treated by $\mathrm{O}_{3}$ ). More precisely, the maximal recovery of the second NF module is achieved when the permeability of the last membranes in the second NF module is equal to the permeability of the last membranes in the first NF module.

Van Geluwe et al. ${ }^{6}$ showed that the alleviation of membrane fouling by $\mathrm{O}_{3}$ treatment is mainly caused by the selective decomposition of unsaturated $\mathrm{C}-\mathrm{C}$ bonds (measured by the $\mathrm{UV}$ absorbance) that are abundant in the hydrophobic fraction of the NOM. As a first-order approximation, assume that membrane fouling is proportional to the UV absorbance of the filtered stream. In that case, the maximal recovery of the second NF module is achieved if the ratio of $C_{R 2}$ (the UV absorbance of the retentate obtained in the second NF module) to $C_{\mathrm{R} 1}$ (the UV absorbance of the retentate obtained in the first NF module) is equal to

$$
\frac{C_{\mathrm{R} 2}}{C_{\mathrm{R} 1}}=\frac{1-U}{1-T}
$$

where $U$ represents the relative membrane permeability without $\mathrm{O}_{3}$ oxidation and $T$ represents the relative membrane permeability with $\mathrm{O}_{3}$ oxidation (see Table 1 ). The ratio $C_{\mathrm{R} 2} /$ $C_{\mathrm{R} 1}$ depends on the recovery $R$ of the second NF module and the retention $r$ of the UV absorbing compounds by the membranes: ${ }^{54}$

$$
\frac{C_{\mathrm{R} 2}}{C_{\mathrm{R} 1}}=\frac{1-R(1-r)}{1-R}
$$

The retention $r$ is calculated on the data in Figure 7 in the work of Van Geluwe et al.: ${ }^{6} r=94.5 \%$ for NF 270, $r=97.6 \%$ for Desal $51 \mathrm{HL}, r=85.5 \%$ for NF-PES 10 , and $r=91.2 \%$ for
NF 90. The maximal recovery $R$ in the second NF module can now be calculated by equating eqs 13 and 14 :

$$
R=\frac{T-U}{T-U+r(1-T)}
$$

This results in $R=52.0 \%$ for NF $270, R=36.5 \%$ for Desal 51 HL, $R=42.3 \%$ for NF-PES 10 , and $R=52.9 \%$ for NF 90 .

3.4. Economic Evaluation. The feasibility of fouling alleviation of $\mathrm{NF}$ membranes by $\mathrm{O}_{3}$ oxidation strongly depends on its economic assessment. An increase of the membrane flux due to $\mathrm{O}_{3}$ oxidation of the NOM decreases the capital and maintenance costs of the subsequent NF module. These cost reductions (savings) should be higher than the total costs of the $\mathrm{O}_{3}$ installation (costs). This is investigated for an integrated NF $+\mathrm{O}_{3}$ installation with a flow rate of $400 \mathrm{~m}^{3} \mathrm{~h}^{-1}$ that removes $34 \%$ of the NOM. The design flow rate of the installation is $20 \%$ higher, to accommodate peaks in the water demand.

The required NF membrane area is calculated with the help of the permeabilities listed in Table 1 . In order to calculate the required membrane area, it is assumed that the pressure difference across the membranes $(\Delta P)$ is 5 bar. The average temperature of the feedwater is assumed to be $10{ }^{\circ} \mathrm{C}$ (instead of $20{ }^{\circ} \mathrm{C}$ during the laboratory-scale experiments). The flux of the NF membranes decreases at lower temperatures and it is assumed that the membrane flux decreases $2.5 \%$ per ${ }^{\circ} \mathrm{C}$ temperature difference. ${ }^{28}$ A flux decline of $10 \%$ per membrane during the lifetime of the membranes is also taken into account. $^{28}$ The required membrane area in the second NF module of the full-scale plant reduces from $14100 \mathrm{~m}^{2}$ to 11000 $\mathrm{m}^{2}$ (for the NF 270 membrane), from $15100 \mathrm{~m}^{2}$ to $11900 \mathrm{~m}^{2}$ (Desal 51), from $16800 \mathrm{~m}^{2}$ to $13000 \mathrm{~m}^{2}$ (NF-PES 10), and from $33500 \mathrm{~m}^{2}$ to $18500 \mathrm{~m}^{2}$ (NF 90), if the retentate solution of the first NF module is oxidized by $\mathrm{O}_{3}$ before it is fed to the second NF module (see Figure 1). The required volume of the $\mathrm{O}_{3}$ reactor and the specific $\mathrm{O}_{3}$ dose can be read out from Figures 8 and 9 (i.e., $10.9 \mathrm{~m}^{3}$ and $18.61 \mathrm{~g} \mathrm{O}_{3}$ per $\mathrm{m}^{3}$, respectively).

The savings and costs are listed in Table 4 (see section 2.4 for more details of the economic computations) and expressed in $€$ per $\mathrm{m}^{3}$ permeate in the second NF module. The permeate flow rate in the second NF module is equal to the product of the feed flow rate $\left(400 \mathrm{~m}^{3} \mathrm{~h}^{-1}\right)$ and the recovery $R$ of this module, which is estimated in section 3.3. The figures in Table 4 show that the cost reductions in the second NF module are higher than the total costs of the $\mathrm{O}_{3}$ installation. This conclusion can be drawn for every investigated membrane and it is especially clear with the NF 90 membrane. This membrane has a rather low permeability, so that a high membrane area is needed, and the flux increases by $31 \%$ after $\mathrm{O}_{3}$ oxidation, which is quite high compared to the other membranes, where a flux increase of $15 \%-18 \%$ could be achieved (see Table 1). The highest amount of money can be saved because less membranes have to be replaced. Concerning the $\mathrm{O}_{3}$ oxidation unit, the capital costs of the contacting equipment are negligible. The capital costs are determined by the purchase costs of the $\mathrm{O}_{3}$ generator and are roughly half of the maintenance costs. The energy cost of the $\mathrm{O}_{3}$ installation is higher than the purchase cost of $\mathrm{O}_{2}$. The total costs of the $\mathrm{O}_{3}$ installation are $\sim 90 \%-93 \%$ of the expected cost reductions in the NF installation, if the membranes NF 270 or Desal 51 are used, $77 \%$ with NF-PES 10 , and $<20 \%$ with NF 90 . This shows that the building of an $\mathrm{O}_{3}$ installation is recommended if the NF-PES 10 or NF 90 membranes are used, although the 
Table 4. Comparison of the Cost Reductions (Savings) of the NF Installation and the Costs of the $\mathrm{O}_{3}$ Oxidation Unit ${ }^{a}$

\begin{tabular}{|c|c|c|c|c|}
\hline membrane & NF 270 & Desal 51 & NF-PES & NF 90 \\
\hline \multicolumn{5}{|l|}{ Cost Reduction: NF } \\
\hline civil investments & 0.0112 & 0.0165 & 0.0167 & 0.0533 \\
\hline mechanical investments & 0.0111 & 0.0164 & 0.0166 & 0.0531 \\
\hline electrotechnical investments & 0 & 0 & 0 & 0 \\
\hline purchase of membranes & 0.0139 & 0.0204 & 0.0206 & 0.0660 \\
\hline energy costs & 0 & 0 & 0 & 0 \\
\hline replacement of membranes & 0.0371 & 0.0547 & 0.0553 & 0.1769 \\
\hline chemical costs & 0 & 0 & 0 & 0 \\
\hline $\begin{array}{l}\text { replacement of miscellaneous } \\
\text { parts }\end{array}$ & 0.0071 & 0.0105 & 0.0106 & 0.0340 \\
\hline Total savings & 0.0805 & 0.1186 & 0.1198 & 0.3833 \\
\hline \multicolumn{5}{|l|}{ Costs: $\mathrm{O}_{3}$ Oxidation } \\
\hline investment $\mathrm{O}_{3}$ generator & 0.0248 & 0.0353 & 0.0305 & 0.0244 \\
\hline $\begin{array}{l}\text { investment contacting } \\
\text { equipment }\end{array}$ & 0.0009 & 0.0013 & 0.0011 & 0.0009 \\
\hline $\mathrm{O}_{2}$ consumption & 0.0218 & 0.0311 & 0.0268 & 0.0214 \\
\hline energy consumption & 0.0252 & 0.0359 & 0.0310 & 0.0248 \\
\hline $\begin{array}{l}\text { replacement of miscellaneous } \\
\text { parts }\end{array}$ & 0.0023 & 0.0033 & 0.0029 & 0.0023 \\
\hline Total costs & 0.0750 & 0.1069 & 0.0923 & 0.0738 \\
\hline Total savings - total costs & 0.0054 & 0.0117 & 0.0275 & 0.3095 \\
\hline \multicolumn{5}{|c|}{ 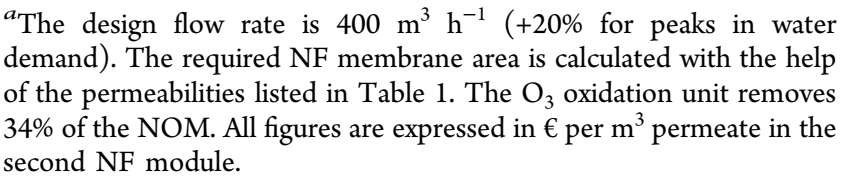 } \\
\hline
\end{tabular}

difference is small $(<20 \%)$ for the NF 270 and Desal 51 membranes. More elaborate calculations are necessary in order to assess whether the investment in an $\mathrm{O}_{3}$ installation is worth considering.

\section{CONCLUSIONS}

Laboratory-scale experiments were performed to locate the regime of the reaction between $\mathrm{NOM}$ and $\mathrm{O}_{3}$ and to determine the enhancement factor $E$, which is necessary to calculate the volume of a reactor on an industrial scale. The $\mathrm{O}_{3}$ reactor is a countercurrent bubble reactor, with plug flow for both the liquid phase and the gas phase. The decomposition of NOM is measured by the UV absorbance at $275 \mathrm{~nm}$, because this is a measure for the concentration of the organic matter that is reactive toward $\mathrm{O}_{3}$ and it is an important factor related to membrane fouling. The first $20 \mathrm{~min}$ of the laboratory-scale experiments are relevant, with regard to upscaling. During this period, the residual $\mathrm{O}_{3}$ concentration in the bulk of the NOM solutions approaches zero when it is compared to the $\mathrm{O}_{3}$ concentration at the gas/liquid interface. It is shown that the Hatta number decreases monotonously as a function of time, from 0.0484 to 0.0045 . The kinetic regime of the reaction between NOM and $\mathrm{O}_{3}$ is slow $\left(M_{H}<0.3\right)$ and the reaction occurs only in the bulk liquid, not in the liquid film. At no time is there an enhancement of the $\mathrm{O}_{3}$ absorption by the chemical reaction in the liquid phase: $E=1$. The reactor volume and the required $\mathrm{O}_{3}$ dose are calculated as a function of the desired decrease of the UV absorbance. For a design flow rate of 480 $\mathrm{m}^{3} \mathrm{~h}^{-1}$, the reactor volume was $8.2 \mathrm{~m}^{3}$ if the UV absorbance is to be decreased by $26 \%$, and $27.6 \mathrm{~m}^{3}$ if the UV absorbance must decrease by $60 \%$. The specific $\mathrm{O}_{3}$ consumption is 14.6 and $33.5 \mathrm{~g} \mathrm{O}_{3}$ per $\mathrm{m}^{3}$ retentate, respectively. The economic assessment shows that the cost reductions in the second NF module are higher than the total costs of the $\mathrm{O}_{3}$ installation. This conclusion can be drawn for every investigated membrane (NF 90, NF 270, Desal 51, and NF-PES 10), although the difference is small $(<20 \%)$ for the NF 270 and Desal 51 membranes, for which more-detailed calculations are necessary.

\section{ASSOCIATED CONTENT}

\section{S Supporting Information}

A Supporting Information section is available separately that presents the mathematical development of the two-film theory with mass transfer and chemical reaction. ${ }^{7}$ The two-film theory for the reaction between $\mathrm{O}_{3}$ and NOM is studied in Section S.1, while Section S.2 reports on the self-decomposition reaction of $\mathrm{O}_{3}$. An overview of literature values for the apparent rate constant $k_{\text {app }}$ is also given (Section S.3). This material is available free of charge via the Internet at http://pubs.acs.org.

\section{AUTHOR INFORMATION}

\section{Corresponding Author}

*Tel.: +32 16322 340. Fax: +32 16322 991. E-mail: eulermascheroni@hotmail.be.

\section{Notes}

The authors declare no competing financial interest.

\section{ACKNOWLEDGMENTS}

S.V.G. is grateful to IWT-Vlaanderen (Institute for the Promotion of Innovation by Science and Technology in Flanders) for providing a fellowship.

\section{NOMENCLATURE}

$\varepsilon=$ gas holdup $\left(\mathrm{m}_{\mathrm{g}}{ }^{3} \mathrm{~m}_{\mathrm{r}}^{-3}\right)$

$1-\varepsilon=$ liquid holdup $\left(\mathrm{m}_{1}^{3} \mathrm{~m}_{\mathrm{r}}^{-3}\right)$

$\mu_{2}=$ dynamic viscosity of water; $\mu_{2}=10^{-3} \mathrm{~Pa} \mathrm{~s}$

$\varphi_{2}=$ association factor for water; $\varphi_{2}=2.26$

$a=$ specific interfacial area $\left(\mathrm{m}_{\mathrm{i}}^{2} \mathrm{~m}_{\mathrm{r}}^{-3}\right)$

$A=$ required membrane area $\left(\mathrm{m}^{2}\right)$

$A(t)=\mathrm{UV}$ absorbance at $275 \mathrm{~nm}$ at time $t\left(\mathrm{~m}^{-1}\right)$

$b=$ ratio of the stoichiometric coefficient of NOM to $\mathrm{O}_{3}$ (assumed to be 1)

$C_{\mathrm{NOM}}=\mathrm{NOM}$ concentration in the liquid bulk $\left(\mathrm{mol} \mathrm{m}_{\mathrm{l}}^{-3}\right)$

$\mathrm{C}_{\mathrm{O}_{3}}=\mathrm{O}_{3}$ concentration in the liquid phase $\left(\mathrm{mol} \mathrm{m}^{-3}\right)$

$\mathrm{C}_{\mathrm{O}_{3}}^{*}=\mathrm{O}_{3}$ concentration at the gas/liquid interface (mol $\mathrm{m}_{1}^{-3}$ )

$\mathrm{C}_{\mathrm{O}_{3}}^{\infty}=\mathrm{O}_{3}$ concentration in the bulk liquid at saturation (mol $\mathrm{m}_{1}^{-3}$ )

$\mathrm{C}_{\mathrm{O}_{3}}^{b}=\mathrm{O}_{3}$ concentration in the bulk liquid $\left(\mathrm{mol} \mathrm{m}_{1}^{-3}\right)$

$d_{b}=$ diameter of the gas bubbles $(\mathrm{m})$

$D_{i}=$ diffusion coefficient of solute $i$ in water at infinite dilution $\left(\mathrm{m}^{2} \mathrm{~s}^{-1}\right)$

$E=$ enhancement factor

$E_{i}=$ enhancement factor for instantaneous reactions

$F=$ liquid flow rate of the $\mathrm{O}_{3}$ reactor $\left(\mathrm{m}_{1}^{3} \mathrm{~h}^{-1}\right)$

$G=$ gas flow rate of the $\mathrm{O}_{3}$ reactor $\left(\mathrm{m}_{\mathrm{g}}{ }^{3} \mathrm{~h}^{-1}\right)$

$H^{*}=$ pseudo-Henry constant $\left(\mathrm{mol} \mathrm{m}_{1}^{-3} \mathrm{~atm}^{-1}\right)$

$\Delta H_{i}=$ latent heat of vaporization of $i$ at its normal boiling point $\left(\mathrm{J} \mathrm{mol}^{-1}\right)$

$h_{L}=$ liquid height without gas bubbling $(\mathrm{m})$

$h_{L+G}=$ liquid height with gas bubbling $(\mathrm{m})$ 
$k_{\text {app }}=$ apparent reaction rate constant between $\mathrm{O}_{3}$ and NOM $\left(\mathrm{mol} \mathrm{m} \mathrm{l}^{-3} \mathrm{~s}^{-1}\right)$

$k_{\mathrm{B}}=$ Boltzmann constant; $k_{\mathrm{B}}=1.38 \times 10^{-23} \mathrm{~m}^{2} \mathrm{~kg} \mathrm{~s}^{-2} \mathrm{~K}^{-1}$

$k_{\mathrm{d}}=$ self-decomposition rate constant of $\mathrm{O}_{3}\left(\mathrm{~s}^{-1}\right)$

$K_{L}=$ overall mass-transfer coefficient of $\mathrm{O}_{3}\left(\mathrm{~m}_{1}^{3} \mathrm{~m}_{\mathrm{i}}^{-2} \mathrm{~s}^{-1}\right)$

$k_{L}=$ mass-transfer coefficient of $\mathrm{O}_{3}$ in the liquid phase $\left(\mathrm{m}_{1}^{3}\right.$ $\left.\mathrm{m}_{\mathrm{i}}^{-2} \mathrm{~s}^{-1}\right)$

$k_{L} a=$ volumetric mass-transfer coefficient of $\mathrm{O}_{3}$ in the liquid phase $\left(\mathrm{m}_{1}^{3} \mathrm{~m}_{\mathrm{r}}^{-3} \mathrm{~s}^{-1}\right)$

$M_{H}=$ Hatta number for the reaction between $\mathrm{O}_{3}$ and $\mathrm{NOM}$

$M_{H 1}=$ Hatta number for the decomposition reaction of $\mathrm{O}_{3}$ in

pure water

$M_{i}=$ molecular mass of $i\left(\mathrm{~g} \mathrm{~mol}^{-1}\right)$

$\mathrm{N}_{\mathrm{O}_{3}}=$ flux of $\mathrm{O}_{3}$ transferred per square meter interfacial area $\left(\mathrm{mol} \mathrm{m}_{\mathrm{i}}^{-2} \mathrm{~s}^{-1}\right)$

$\Delta P=$ transmembrane pressure (atm)

$P_{\mathrm{O}_{3}}^{*}=$ partial pressure of $\mathrm{O}_{3}$ at the gas-liquid interface (atm)

$P_{\mathrm{O}_{3}}=$ partial pressure of $\mathrm{O}_{3}$ in the gas bulk (atm)

$r_{\mathrm{O}_{3}}=$ flux of $\mathrm{O}_{3}$ transferred per cubic meter reactor volume $\left(\mathrm{mol} \mathrm{m}_{\mathrm{r}}^{-3} \mathrm{~s}^{-1}\right)$

$T=$ temperature $(\mathrm{K})$

$V_{i}=$ molar volume of $i$ at its normal boiling point $\left(\mathrm{cm}^{3}\right.$ $\mathrm{mol}^{-1}$ )

$V_{r}=$ volume of the $\mathrm{O}_{3}$ reactor $\left(\mathrm{m}^{3}\right)$

\section{REFERENCES}

(1) de la Rubia, A.; Rodríguez, M.; León, V. M.; Prats, D. Removal of natural organic matter and THM formation potential by ultra- and nanofiltration of surface water. Water Res. 2008, 42, 714.

(2) Verliefde, A.; Cornelissen, E.; Amy, G.; Van der Bruggen, B.; van Dijk, H. Priority organic micropollutants in water sources in Flanders and the Netherlands and assessment of removal possibilities with nanofiltration. Environ. Pollut. 2007, 146, 281.

(3) Nederlof, M. M.; van Paassen, J. A. M.; Jong, R. Nanofiltration concentrate disposal: Experiences in the Netherlands. Desalination 2005, 178, 303.

(4) Shannon, M. A.; Bohn, P. W.; Elimelech, M.; Georgiadis, J. G.; Mariñas, B. J.; Mayes, A. M. Science and technology for water purification in the coming decades. Nature 2008, 452, 301.

(5) Van Geluwe, S.; Braeken, L.; Van der Bruggen, B. Ozone oxidation for the alleviation of membrane fouling by natural organic matter: A review. Water Res. 2011, 45, 3551.

(6) Van Geluwe, S.; Vinckier, C.; Braeken, L.; Van der Bruggen, B. Ozone oxidation of nanofiltration concentrates alleviates membrane fouling in drinking water industry. J. Membr. Sci. 2011, 378, 128.

(7) Lewis, W. K.; Whitman, W. G. Principles of gas absorption. Ind. Eng. Chem. 1924, 16, 1215.

(8) Sotelo, J. L.; Beltrán, F. J.; Benítez, F. J.; Beltrán, J. Ozone decomposition in water: Kinetic study. Ind. Eng. Chem. Res. 1987, 26, 39.

(9) Kumar, R.; Bose, P. Development and experimental validation of the model of a continuous-flow countercurrent ozone contactor. Ind. Eng. Chem. Res. 2004, 43, 1418.

(10) Tiwari, G.; Bose, P. Development and experimental validation of the model of a tall, continuous-flow, countercurrent, bubble-type ozone contactor. Ind. Eng. Chem. Res. 2006, 45, 109.

(11) Cockx, A.; Do-Quang, Z.; Liné, A.; Roustan, M. Use of computational fluid dynamics for simulating hydrodynamics and mass transfer in industrial ozonation towers. Chem. Eng. Sci. 1999, 54, 5085.

(12) Kim, J. H.; Elovitz, M. S.; von Gunten, U.; Shukairy, H. M.; Mariñas, B. J. Modeling Cryptosporidium parvum oocyst inactivation and bromate in a flow-through ozone contactor treating natural water. Water Res. 2007, 41, 467.

(13) Talvy, S.; Debaste, F.; Martinelli, L.; Chauveheid, E.; Haut, B. Development of a tool, using CFD, for the assessment of the disinfection process by ozonation in industrial scale drinking water treatment plants. Chem. Eng. Sci. 2011, 66, 3185.

(14) Ventresque, C.; Gisclon, V.; Bablon, G.; Chagneau, G. An outstanding feat of modern technology: The Mery-sur-Oise nanofiltration treatment plant $\left(340,000 \mathrm{~m}^{3} / \mathrm{d}\right)$. Desalination 2000, 131, 1.

(15) Song, W.; Ravindran, V.; Koel, B. E.; Pirbazari, M. Nanofiltration of natural organic matter with $\mathrm{H}_{2} \mathrm{O}_{2} / \mathrm{UV}$ pretreatment: Fouling alleviation and membrane surface characterization. J. Membr. Sci. 2004, 241, 143.

(16) Staehelin, J.; Hoigné, J. Decomposition of ozone in water in the presence of organic solutes acting as promoters and inhibitors of radical chain reactions. Environ. Sci. Technol. 1985, 19, 1206.

(17) von Gunten, U. Ozonation of drinking water: Part I. Oxidation kinetics and product formation. Water Res. 2003, 37, 1443.

(18) Lucas, M. S.; Peres, J. A.; Lan, B. Y.; Puma, G. L. Ozonation kinetics of winery wastewater in a pilot-scale bubble column reactor. Water Res. 2009, 43, 1523.

(19) Hoigné, J.; Bader, H. Rate constants of reactions of ozone with organic and inorganic compounds in water-I: Non-dissociating organic compounds. Water Res. 1983, 17, 173.

(20) Hoigné, J.; Bader, H. Rate constants of reactions of ozone with organic and inorganic compounds in water-II: Dissociating organic compounds. Water Res. 1983, 17, 185.

(21) Beltrán, F. J. Ozone Reaction Kinetics for Water and Wastewater Systems; CRC Press: Boca Raton, FL, 2004.

(22) Muroyama, K.; Norieda, T.; Morioka, A.; Tsuji, T. Hydrodynamics and computer simulation of an ozone oxidation reactor for treating drinking water. Chem. Eng. Sci. 1999, 54, 5285.

(23) Hoigné, J.; Bader, H. Ozonation of water: Oxidationcompetition values of different types of waters in Switzerland. Ozone Sci. Eng. 1979, 1, 357.

(24) Westerhoff, P.; Aiken, G.; Amy, G.; Debroux, J. Relationships between the structure of natural organic matter and its reactivity towards molecular ozone and hydroxyl radicals. Water Res. 1999, 33, 2265.

(25) Elovitz, M. S.; von Gunten, U.; Kaiser, H. P. Hydroxyl radical/ ozone ratios during ozonation processes. II. The effect of temperature, pH, alkalinity, and DOM properties. Ozone Sci. Eng. 2000, 22, 123.

(26) Peuravuori, J.; Pihlaja, K. Characterization of freshwater humic matter. In Handbook of Water Analysis, 2nd ed.; Nollet, L. M. L., Ed.; CRC Press: Boca Raton, FL, 2007.

(27) CPI inflation calculator. (Available via the Internet at http:// data.bls.gov/cgi-bin/cpicalc.pl, last visited on July 5, 2011.)

(28) Van der Bruggen, B.; Everaert, K.; Wilms, D.; Vandecasteele, C. Application of nanofiltration for removal of pesticides, nitrate and hardness from ground water: Rejection properties and economic evaluation. J. Membr. Sci. 2001, 193, 239.

(29) Lobo, W. S.; Ried, A. Advanced oxidation processes (AOP). The next "silver bullet"... but which process is the best? A comparison of treatment processes combining ozone, UV, and hydrogen peroxide. In Proceedings of the World Congress on Ozone and Ultraviolet Technologies, Los Angeles, CA, August 27-29, 2007.

(30) Spartan Water Treatment. Ozone generators feed gas economics. (Available via the Internet at http://www. spartanwatertreatment.com/Ozone-Generator-Feed-Gas-Economics. html, last visited on March 15, 2011.)

(31) Ray Sharma, J. Development of a preliminary cost estimation method for water treatment plants, 2010. (Available via the Internet at http://dspace.uta.edu/bitstream/handle/10106/4924/Sharma_uta 2502M_10652.pdf?sequence $=1$, last visited on July 28, 2011.)

(32) Taylor, R.; Krishna, R. Multicomponent Mass Transfer; Wiley: New York, 1993.

(33) Evans, D. F.; Tominaga, T.; Davis, H. T. Tracer diffusion in polyatomic liquids. J. Chem. Phys. 1981, 74, 1298.

(34) Wilke, C. R; Chang, P. Correlation of diffusion coefficients in dilute solutions. AIChE J. 1955, 1, 264.

(35) Hayduk, W.; Laudie, H. Prediction of diffusion coefficients for nonelectrolytes in dilute aqueous solutions. AIChE J. 1974, 20, 611. 
(36) King, C. J.; Hsueh, L.; Mao, K. W. Liquid phase diffusion of nonelectrolytes at high dilution. J. Chem. Eng. Data 1965, 10, 348.

(37) Nakanishi, K. Prediction of diffusion coefficient of nonelectrolytes in dilute solution based on generalized Hammond-Stokes plot. Ind. Eng. Chem. Fundam. 1978, 17, 253.

(38) Hayduk, W.; Minhas, B. S. Correlations for prediction of molecular diffusivities in liquids. Can. J. Chem. Eng. 1982, 60, 295. (And correction: Can. J. Chem. Eng. 1983, 61, 132.)

(39) Siddiqi, M. A.; Lucas, K. Correlations for prediction of diffusion in liquids. Can. J. Chem. Eng. 1986, 64, 839.

(40) Matrozov, V.; Kachtunov, S.; Stepanov, A.; Tegunov, B. Experimental determination of the molecular diffusion coefficient of ozone in water. Zh. Prikl. Khim. 1976, 49, 1070.

(41) Johnson, P. N.; Davis, R. A. Diffusivity of ozone in water. J. Chem. Eng. Data 1996, 41, 1485.

(42) Thorsen, T. Concentration polarisation by natural organic matter (NOM) in NF and UF. J. Membr. Sci. 2004, 233, 79.

(43) Her, N.; Amy, G.; McKnight, D.; Sohn, J.; Yoon, Y. Characterization of DOM as a function of $\mathrm{MW}$ by fluorescence EEM and HPLC-SEC using UVA, DOC and fluorescence detection. Water Res. 2003, 37, 4295.

(44) Kreyszig, E. Advanced Engineering Mathematics, 9th ed.; Wiley: New York, 2006.

(45) De Smedt, F.; De Gendt, S.; Heyns, M. M.; Vinckier, C. The application of ozone in semiconductor cleaning processes: The solubility issue. J. Electrochem. Soc. 2001, 148, G487.3.

(46) Benefield, L. D.; Judkins, J. F.; Weand, B. L. Process Chemistry for Water and Wastewater Treatment; Prentice Hall: Englewood Cliffs, NJ, 1982.

(47) Perry, R. H.; Green, D. W. Perry's Chemicals Engineers' Handbook, 7th ed.; McGraw-Hill: New York, 1997.

(48) Jansen, R. H. S.; Zwijnenburg, A.; van der Meer, W. G. J.; Wessling, M. Outside-in trimming of humic substances during ozonation in a membrane contactor. Environ. Sci. Technol. 2006, 40, 6460.

(49) Miao, H.; Tao, W. Ozonation of humic acid in water. J. Chem. Technol. Biotechnol. 2008, 83, 336.

(50) Gurol, M. D.; Singer, P. C. Kinetics of ozone decomposition: A dynamic approach. Environ. Sci. Technol. 1982, 16, 377.

(51) Leiknes, T.; Phattaranawik, J.; Boller, M.; von Gunten, U.; Pronk, W. Ozone transfer and design concepts for NOM decolourization in tubular membrane contactor. Chem. Eng. J. 2005, $111,53$.

(52) Chen, Y. H.; Chang, C. Y.; Chiu, C. Y.; Huang, W. H.; Yu, Y. H.; Chiang, P. C.; Ku, Y.; Chen, J. N. Dynamic model of ozone contacting process with oxygen mass transfer in bubble columns. J. Environ. Eng. 2002, 128, 1036.

(53) Rakness, K. L.; Hunter, G. F. Ozone: Water treatment applications, equipment and safety. Presented at the International Ozone Association Meeting, Lake Lanier, GA, 2005. (Available via the Internet at http://www.spartanwatertreatment.com/ozone-drinkingwater-presentation.html, last visited on May 25, 2011.)

(54) Van Geluwe, S.; Braeken, L.; Robberecht, T.; Jans, M.; Creemers, C.; Van der Bruggen, B. Evaluation of electrodialysis for scaling prevention of nanofiltration membranes at high water recoveries. Res. Cons. Recycl. 2011, 56, 34.

(55) Rakness, K. L.; Medard, L. Gas Encyclopedia; Elsevier/Air Liquide: Amsterdam, the Netherlands, 1976. 